\title{
Tree Diversity at La Mesa Watershed in Luzon, a Reforested Urban Watershed
}

\author{
PASTOR L. MALABRIGO, JR.
}

ORCID No. 0000-0002-4254-751X

plmalabrigo@up.edu.ph

Associate Professor, Department of Forest Biological Sciences,

College of Forestry and Natural Resources,

University of the Philippines Los Baños,

College, Los Baños, Laguna 4031, Philippines

\section{CRISTINO L. TIBURAN, JR.}

ORCID No. 0000-0002-0863-4089

cltiburan@up.edu.ph

Assistant Professor, Institute of Renewable Natural Resources,

College of Forestry and Natural Resources,

University of the Philippines Los Baños,

College, Los Baños, Laguna 4031, Philippines

\section{MARCO A. GALANG}

ORCID No. 0000-0001-8942-3437

magalang@uplb.edu.ph

Assistant Professor, Institute of Renewable Natural Resources,

College of Forestry and Natural Resources,

University of the Philippines Los Baños,

College, Los Baños, Laguna 4031, Philippines

\section{IZURU SAIZEN}

ORCID No. 0000-0002-7065-0098

saizen.iz@gmail.com

Associate Professor, Laboratory of Regional Planning,

Graduate School of Global Environmental Studies,

Kyoto University, Kyoto, Japan 


\section{ABSTRACT}

The condition of a watershed is vital to its provision of goods and services. Unfortunately, in the Philippines, a lot of watersheds are degraded due to various causes like deforestation and mining. Restoration of these areas has been initiated through reforestation, with limited information generated on the impact of such practice to the overall tree diversity in the area. As such, a study was conducted at La Mesa Watershed (LMW), situated near an urban area, to determine the impact of reforestation on tree diversity. Data were generated through a field inventory of trees following a stratified cluster sampling technique where the area was subdivided into three elevation classes ( $<100$ masl, 100-150 masl and $>150$ masl) and a corresponding number of plots were established in each classes. Results showed a relatively high diversity of native trees with 70 species of the total 92 . Fourteen species are found to be endemic to the country while 7 species are listed in either the IUCN or Philippine Red List.. The current vegetation in LMW shows a rare success story of reforestation efforts in the country implemented through private-public partnerships.

Keywords: La Mesa Watershed, restoration, plant diversity, endemism, environmental services

\section{INTRODUCTION}

Watersheds play an important role in a country's development as it provides valuable resources to society. An intact watershed can assure a regulated flow of water for power generation, and domestic and industrial use. Similarly, a wellmanaged watershed reduces flood and landslide hazards. In essence, a sustainably managed watershed can provide an array of on-site and off-site economic, social and environmental benefits (DOST et al. 1999).

Unfortunately, a lot of watersheds in the Philippines have been degraded due to over extraction of timber resources, illegal logging, charcoal making, and mining, among others. Consequently, various environmental calamities like flooding during the rainy season, drought during summer months, reduced water supply for hydroelectric power generation, and landslide events have occurred, damaging infrastructures, taking lives, and hindering national development. These consequences support the idea that in a watershed, the cumulative effects of individual actions can devastate the quality of water resources and human 
activities (Gonenc et al. 2008).

Recognizing the value of watersheds, the Philippine government and private organizations launched numerous reforestation efforts, with the aim of restoring forest vegetation and sustaining the environmental services the watershed provides. The reforestation of La Mesa Watershed (LWM), a watershed in an urban setting that supports the Philippine's national capital region, exemplifies this kind of initiative.

The La Mesa Watershed has experienced severe degradation in the 1960's and 1970's due to slash and burn activities. From 1978-1983, the Manila Seedling Bank Foundation, Inc. (MSBFI) undertook reforestation of the area. However, when MSBFI left the site, illegal loggers exploited the area. In 1999, the "Bantay Kalikasan" (BK) of the ABS-CBN Foundation, Inc., signed an agreement with the Metropolitan Waterworks and Sewerage System (MWSS) giving the former authority to reforest and administer the area (Tiburan et al. 2012). During these periods, Kaatoan bangkal (Neolamarckia cadamba (Roxb.) Bosser), Kupang (Parkia timoriana (DC) Merr.), and Big leaf mahogany (Swietenia macrophylla King), among others, have been planted in the area. To date, it is still managed and reforested by BK.

Reforestation of degraded watersheds can be viewed as an initial attempt to reestablish the environmental services provided by watersheds. The main goal could be the restoration of vegetation, which once dominated the site. It is imperative, therefore, to assess the success of forest restoration (DellaSala et al. 2003) as it is also indicative of the present and future conditions of watersheds. One of the indicators of this success is the level of biodiversity of tree species after reforestation. Currently, this information is lacking, especially for a watershed set in an urban environment that has been reforested periodically. The general objective of this research is to provide that information. In particular, it would like to determine the impact of the reforestation made during the 90's, on tree diversity particularly on forest succession leading to recruitment of native species in the area. The results of which, can be used in mapping out future activities (e.g. the need for active restoration) in order to ensure sustainable watershed services.

\section{Description of the Study Area}

The La Mesa Watershed (LMW) is located in the northern most part of Metro Manila where majority of the area is covered by Quezon City. It has a total area of about 2,659 ha including its reservoir which is approximately 365 ha (Figure 1). The watershed is a government property titled to the Metropolitan Waterworks and Sewerage System (MWSS) that was initially commissioned in 1929. MWSS 
is the main agency that provides water supply to Metro Manila and other neighboring municipalities. However, when the Water Crisis Act was passed into law, private participation was implemented in the agency through a concession contract. The west zone of Metro Manila has been contracted to the Maynilad Water Services, Inc. while the east zone to the Manila Water Company, Inc. In 2007, LMW was proclaimed into a watershed reservation through Proclamation No. 1336 that primarily aims to protect and improve the water quality, quantity and security of the reservation. Under this law, the management of the area shall be under the joint administrative jurisdiction of MWSS and the Department of Environment and Natural Resources.

At present, however, LMW is still being managed by Bantay Kalikasan of the ABS-CBN Foundation, Inc. through a memorandum of agreement that was forged way back in 1999. Bantay Kalikasan or Nature Watch started on July 21, 1998 and was supported by multi-sector network of government agencies, private institutions and non-government organizations. Its main intention is to serve as a catalyst in addressing the concern over the worsening state of the Philippine environment characterized by air and water pollution, forest denudation, irresponsible waste disposal and their life threatening effects (www. bantaykalikasan.com).

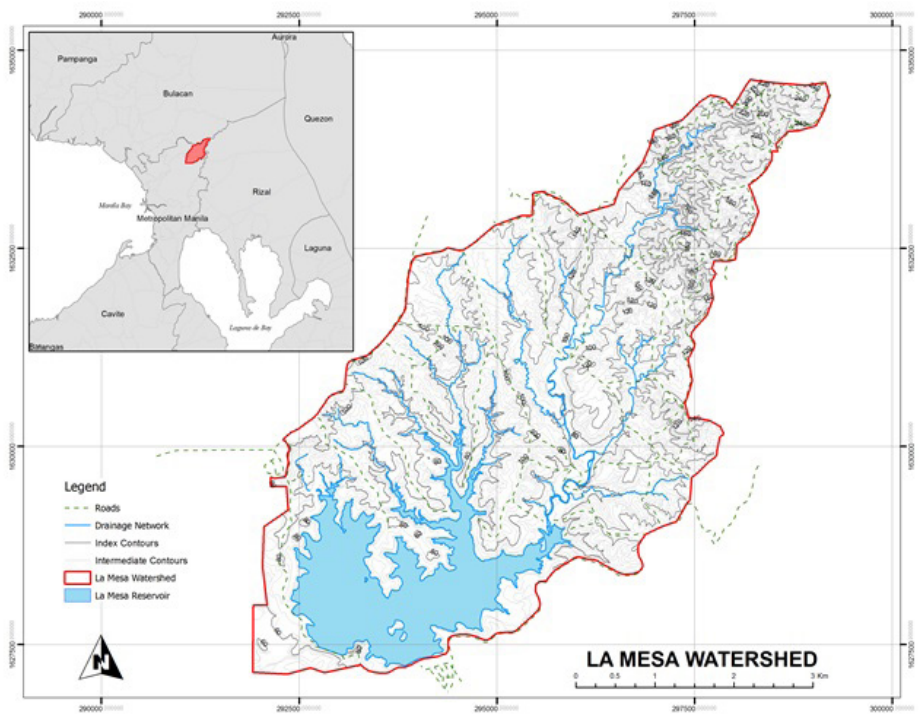

Figure 1. Location map of La Mesa Watershed. 
In terms of the topography in the area, LMW is characterized by a gently undulating terrain with elevations ranging from 46 to 256 masl and slopes below $25 \%$. There are two major soil types in the area and these are the Novaliches and Marikina Series. The Novaliches series are reddish brown in color and its surface and subsoil are friable in consistency and granular in structure. The Marikina series, on the other hand, is a typical recent alluvial soil that occupies all of Marikina Valley from the municipality of Montalban to Pateros. The surface soil is medium or light brown in color and just below the surface soil is a horizon of very dark brown to dark gray in color. The presence of a dark-colored horizon in the subsoil is an indicative of good drainage.

Meanwhile, the climate condition of LMW belongs to Climate Type I of the Modified Coronas Classification of the Philippine Atmospheric, Geophysical and Astronomical Services Administration or PAGASA. This is described by two pronounced seasons - rainy season is from the month of May to December where it usually peaks during July until September. This is due mainly to tropical cyclones, monsoons, local thunderstorm and the inter-tropical converging zone. The mean annual rainfall at LMW from 1978 to 2007 is estimated around 2,514.60 mm while the average monthly minimum and maximum temperatures in the watershed are approximately around $22.920 \mathrm{C}$ and $32.140 \mathrm{C}$, respectively.

Some portions of the area are still covered with natural vegetation with sparsely distributed primary and secondary growth vegetation. These consist mainly of kaatoang bangkal, mahogany, yemane (Gmelina arborea Roxb.), narra (Pterocarpus indicus Willd.), rain tree (Samanea saman (Jacq.) Merr.), santol (Sandoricum koetjape (Burm.f.) Merr.), benguet pine (Pinus kesiya Royle ex Gordon subsp. insularis (Endl.) DZ Li), mango (Mangifera indica L.), acacia (Acacia auriculiformis A Cunn. ex Benth.), bamboo (Bambusa sp.), molave (Vitex parviflora Juss.) and several non-commercial wood species as well. In addition, some species of grasses and shrubs also thrive in the area, which include cogon (Imperata cylindrica (L.) P. Beauv.), hagonoy (Chromolaena odorata (L.) King \& H.E. Robins.), kamoteng kahoy (Manihot esculenta Crantz), carabao grass (Paspalum conjugatum P.J.Bergius), kudzu (Pueraria montana (Lour.) Merr.), and makahiya (Mimosa pudica L.), among others.

\section{OBJECTIVES OF THE STUDY}

The research study generally aimed to assess the current level of tree biodiversity in LMW after more than two decades of reforestation. In particular, 
it determined the effects of the reforestation on forest succession and recruitment of native species; and, the biodiversity value of the watershed by looking at the number of endemic and threatened species in the area.

\section{METHODOLOGY}

\section{Sampling Design and Inventory}

The sampling design used in the study follows a combination of stratified and cluster sampling techniques. The Forest Inventory and Analysis (FIA) program of the US Forest Service used a similar method where it utilized satellite images for stratifying the initial phase of the forest inventory then an actual inventory using cluster sampling was employed in the second phase (Smith 2002). In this study, however, the elevation range was used to stratify the area into different classes. Three elevation ranges were identified: $<100$ masl, 100-150 masl and $>150$ masl. From this stratification, the locations of the center plots for the cluster sampling were randomly identified in the watershed. Accessibility was also taken into consideration in the selection of these center plots. A total of 12 locations were selected for the cluster sampling (Figure 2). The number of representative samples for each elevation class is also proportionally distributed to the area of each class. Hence, there are 6 cluster samples for the $<100$ masl class, 4 cluster samples for the 100-150 masl range, and 2 cluster samples for the $>150$ masl class. Cluster sampling is highly suggested for estimating rare and clustered populations especially those that are difficult to estimate precisely using conventional sampling methods (Thompson 1991; Roesch 1993; Talvitie et al. 2006). With the nature of LMW being a plantation forest, cluster sampling was considered as an appropriate design to capture the biodiversity of the area especially the recruitment of native tree species after reforestation. Each cluster was comprised of a center plot from where all other plots within the cluster were established. A total of five (5) sampling plots were laid out in each cardinal direction (north, south, east and west) with a 50-m interval between plots (Figure 3). This means that in every cluster, a total of 21 sampling plots were established covering a total of 252 plots for the entire reservation (See Figure 2). The size of the sampling plot was set to $10 \mathrm{~m} \times 10 \mathrm{~m}$ and all timber species with a diameter at breast height (dbh) of $\geq 5 \mathrm{~cm}$ were measured and recorded.

Information gathered in the field were tabulated and analyzed to characterize floral composition within the study area. The relative density, relative dominance and relative frequency values for each species were determined to obtain their 
Importance Value (IV), which is the standard measurement in forest ecology to determine the rank relationships of species. Importance values were determined using the following formula:

\begin{tabular}{|c|c|c|}
\hline Density & $=$ & $\frac{\text { number of individuals }}{\text { area sampled }}$ \\
\hline Relative Density & $=$ & density for a species x 100 \\
\hline Frequency & $=$ & $\begin{array}{l}\text { total density for all species } \\
\text { number of plots in which species occur } \\
\text { total number of plots sampled }\end{array}$ \\
\hline Relative Frequency & $=$ & $\begin{array}{l}\text { frequency value for a species x } 100 \\
\text { total frequency for all species }\end{array}$ \\
\hline Dominance & $=$ & $\begin{array}{l}\text { basal area or volume for a species } \\
\text { area sampled }\end{array}$ \\
\hline Relative Dominance & $=$ & $\frac{\text { dominance for a species } \times 100}{\text { total dominance for all species }}$ \\
\hline Importance Value & $=$ & $\begin{array}{l}\text { Relative Density + Relative Frequency + } \\
\text { Relative Dominance }\end{array}$ \\
\hline
\end{tabular}

Endemism and ecological status of the different species were assessed to determine the ecological importance of the vegetation in the area. Species names followed the latest Angiosperm Phylogeny Group classification while the common names adapted that of Rojo (1998). 


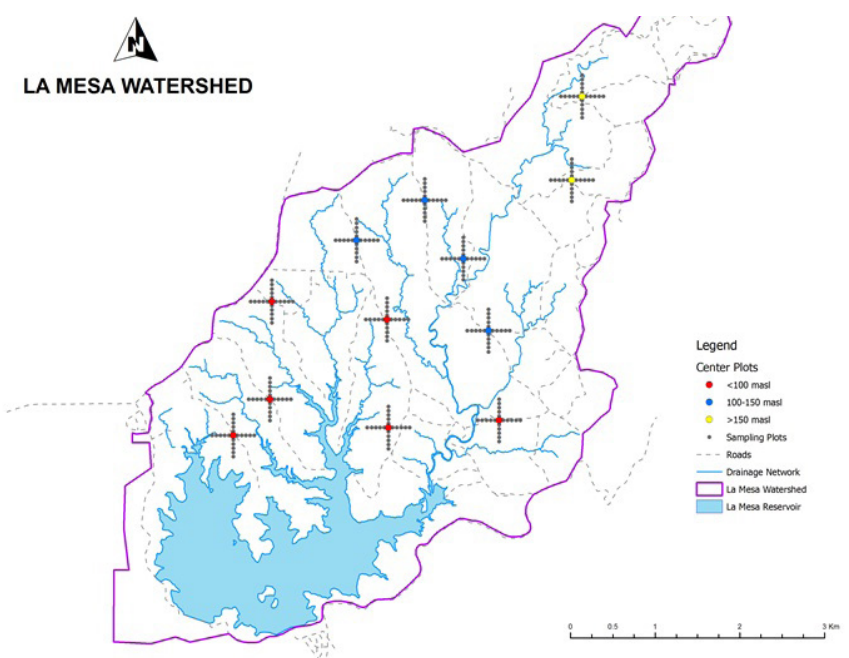

Figure 2. Location of Center Plots Across Different Elevation Classes in the La Mesa Watershed.

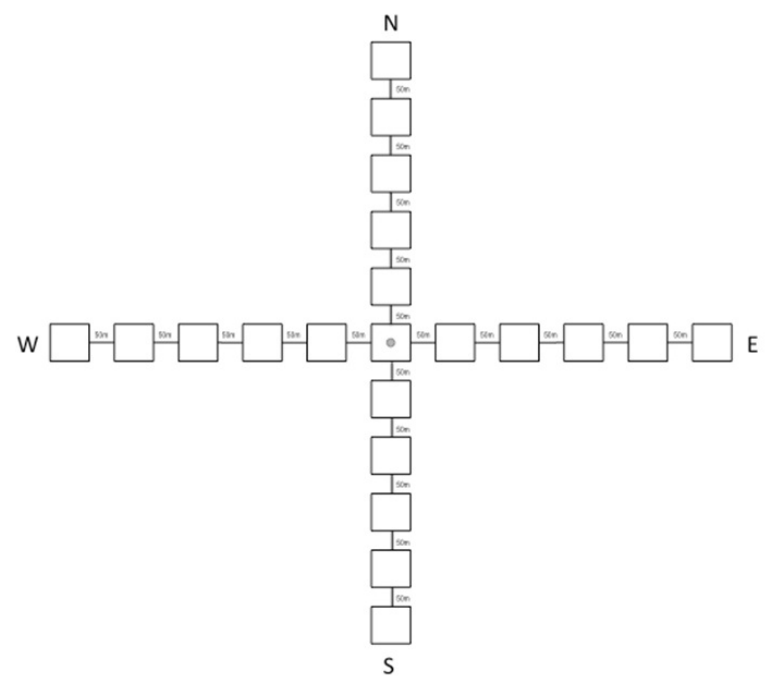

Figure 3. Cluster Sampling Design for the La Mesa Watershed. 


\section{RESULTS AND DISCUSSION}

\section{Stand Structure}

A total of 1,538 individuals belonging to 92 tree species were recorded to have a diameter of more than $5 \mathrm{~cm}$. The average number of trees per plot is about 6 individuals or an average density of 0.06 tree $/ \mathrm{m}^{2}$ ( 6 trees for every 100 $\mathrm{m}^{2}$ ). The computed density is higher than most of the natural forests (about $.04-.05$ tree $/ \mathrm{m}^{2}$ ) understandably because of the planted exotics in the area. The average diameter of all trees is only $15.64 \mathrm{~cm}$. Only four (4) individuals recorded a diameter of more than $70 \mathrm{~cm}$. All belong to the same species, Gmelina.

Based on the computed importance value (the summation of relative density, relative dominance and relative frequency values for each tree species), the five most important species (Table 1) are Gmelina (92.16), Acacia (30.36), Tibig (Ficus nota (Blanco) Merr.) (21.27), Big leaf mahogany (20.33), and Kaatoang bangkal (16.68). Except for Tibig, all species are planted exotics. Tibig, on the other hand, is a highly versatile pioneer species that grows in a wide range of elevation and temperature.

\section{Species Diversity}

Ninety-two (92) tree species belonging to 70 genera and 33 families were documented from the study area (see Table 1 ). Seventy (70) species are indigenous while 22 are introduced to the country. The genus Ficus (figs) has the most number of species with five, followed by Antidesma and Canarium with 3 each. In terms of Family, the most speciose are Fabaceae with 16 species, Moraceae (9), and Euphorbiaceae and Lamiaceae with 6 each. 
Table 1. Taxonomic List of All Species Recorded in the Area and their Importance Value (IV)

\begin{tabular}{|c|c|c|}
\hline Species & Family & IV \\
\hline Gmelina arborea Roxb. & Lamiaceae & 92.16 \\
\hline Acacia auriculiformis A Cunn. ex Benth. & Fabaceae & 30.36 \\
\hline Ficus nota (Blanco) Merr. & Moraceae & 21.27 \\
\hline Swietenia macrophylla King & Meliaceae & 20.33 \\
\hline Neolamarckia cadamba (Roxb.) Bosser & Rubiaceae & 16.68 \\
\hline Pterocarpus indicus Willd. forma indicus & Fabaceae & 12.59 \\
\hline Leucaena leucocephala $(\mathrm{Lam}$.$) de Wit$ & Fabaceae & 12.06 \\
\hline Ficus septica Bum. f & Moraceae & 8.13 \\
\hline Parkia timoriana (DC) Merr. & Fabaceae & 7.03 \\
\hline Macaranga tanarius (L.) Muell-Arg. & Euphorbiaceae & 5.73 \\
\hline Artocarpus blancoi (Elmer) Merr. & Moraceae & 5.23 \\
\hline Canarium asperum Benth. ssp. asperum var. asperum & Burseraceae & 3.75 \\
\hline Melanolepis multiglandulosa (Reinw. ex Blume) Reich.f. \& Zoll. & Euphorbiaceae & 3.74 \\
\hline Vitex parviflora Juss. & Lamiaceae & 3.55 \\
\hline Antidesma montanum Blume & Euphorbiaceae & 2.90 \\
\hline Lagerstroemia speciosa $(\mathrm{L}$.) Pers. & Lythraceae & 2.77 \\
\hline Albizia procera (Roxb.) Benth & Fabaceae & 2.76 \\
\hline Litsea glutinosa (Lour.) C Robinson & Lauraceae & 2.02 \\
\hline Wrightia pubescens R Br. ssp. laniti (Blanco)Ngan & Apocynaceae & 2.02 \\
\hline Ardisia squamulosa $\mathrm{C}$ Presl & Primulaceae & 1.87 \\
\hline Buchanania arborescens (Blume) Blume & Anacardiaceae & 1.82 \\
\hline Streblus asper Lour. & Moraceae & 1.68 \\
\hline Spathodea campanulata Beauv. & Bignoniaceae & 1.62 \\
\hline Semecarpus cuneiformis Blanco & Anacardiaceae & 1.48 \\
\hline Sapindus saponaria $\mathrm{L}$. & Sapindaceae & 1.47 \\
\hline Bauhinia malabarica Roxb. & Fabaceae & 1.38 \\
\hline Antidesma bunius (L.) Spreng var. bunius & Euphorbiaceae & 1.34 \\
\hline Melicope triphylla (Lam.) Merr. & Rutaceae & 1.28 \\
\hline
\end{tabular}




\begin{tabular}{|c|c|c|}
\hline Species & Family & IV \\
\hline Chionanthus ramiflorus Roxb. & Oleaceae & 1.27 \\
\hline Cordia dichotoma $\mathrm{G}$ Forst. & Boraginaceae & 1.23 \\
\hline Artocarpus ovatus Blanco & Moraceae & 1.21 \\
\hline Grewia multiflora Juss. & Malvaceae & 1.21 \\
\hline Bischofia javanica Blume & Phyllanthaceae & 1.20 \\
\hline Sandoricum koetjape (Bum.f.) Merr. & Meliaceae & 1.08 \\
\hline Macaranga bicolor Muell.-Arg. & Euphorbiaceae & 1.08 \\
\hline Ficus pseudopalma Blanco & Moraceae & 1.01 \\
\hline Guioa koelreuteria (Blanco)Merr. & Sapindaceae & 1.00 \\
\hline Salmalia malabarica (DC) Schott \& Endl. & Malvaceae & 0.96 \\
\hline Senna spectabilis (DC) Irwin \& Bameby & Fabaceae & 0.87 \\
\hline Antidesma ghaesembilla Gaertn. & Euphorbiaceae & 0.81 \\
\hline Cratoxylum sumatranum (Jack) Blume ssp. sumatranum & Hypericaceae & 0.80 \\
\hline Terminalia microcarpa Decne. & Combretaceae & 0.74 \\
\hline Acacia mangium Willd. & Fabaceae & 0.70 \\
\hline Bauhinia monandra Kurz & Fabaceae & 0.67 \\
\hline Pinus kesiya Royle ex Gordon subsp. insularis (Endl.) DZ Li & Pinaceae & 0.64 \\
\hline Canarium gracile Engl. & Burseraceae & 0.61 \\
\hline $\begin{array}{l}\text { Symplocos cochinchinensis (Lour.) S Moore var. philippinensis } \\
\text { (Brand) Noot. }\end{array}$ & Symplocaceae & 0.61 \\
\hline Memecylon lanceolatum Blanco & Melastomataceae & 0.60 \\
\hline Barringtonia acutangula (L.) Gaertn. ssp. acutangula & Lecythidaceae & 0.53 \\
\hline Millettia pinnata (L.) Panigrahi & Fabaceae & 0.47 \\
\hline Psidium guajava $\mathrm{L}$. & Myrtaceae & 0.47 \\
\hline Canthium monstrosum (A Rich.) Merr. & Rubiaceae & 0.47 \\
\hline Syzygium cumini (L.) Skeels & Myrtaceae & 0.47 \\
\hline Dracontomelon edule (Blanco) Skeels & Anacardiaceae & 0.47 \\
\hline Neonaucleaglabra (Roxb.) Bakh.f. \& Ridsd. & Rubiaceae & 0.41 \\
\hline
\end{tabular}




\begin{tabular}{|c|c|c|}
\hline Species & Family & IV \\
\hline Syzygium calubcob (C Robinson) Merr. & Myrtaceae & 0.40 \\
\hline Premna odorata Blanco & Lamiaceae & 0.40 \\
\hline Breynia vitis-idaea (Burm.f.) CEC Fischer & Phyllanthaceae & 0.40 \\
\hline Ficus ulmifolia Lam. & Moraceae & 0.40 \\
\hline Albizia acle (Blanco) Merr. & Fabaceae & 0.40 \\
\hline Annona muricata $\mathrm{L}$. & Annonaceae & 0.40 \\
\hline Tectona grandis L. & Lamiaceae & 0.40 \\
\hline Ziziphus talanai (Blanco)Merr. & Rhamnaceae & 0.33 \\
\hline Mangifera indica L. & Anacardiaceae & 0.27 \\
\hline Premna cumingiana Schauer & Lamiaceae & 0.27 \\
\hline Annona atemoya Hort. & Annonaceae & 0.27 \\
\hline Senna siamea (Lam.) Irwin \& Bameby & Fabaceae & 0.27 \\
\hline Broussonetia luzonica (Blanco) Bureau var. luzonica & Moraceae & 0.27 \\
\hline Adenanthera pavonina $\mathrm{L}$. & Fabaceae & 0.27 \\
\hline Delonix regia (Boj,) Raf. & Fabaceae & 0.20 \\
\hline Ficus minahassae (Teijsm. \& Vriese) Miq. & Moraceae & 0.20 \\
\hline Enterolobium cyclocarpum (Jacq.) Griseb. & Fabaceae & 0.20 \\
\hline Cleidion javanicum Blume & Euphorbiaceae & 0.20 \\
\hline Leucosyke capitellata (Poir.) Wedd. & Urticaceae & 0.20 \\
\hline Mallotus cumingii Muell.-Arg. & Euphorbiaceae & 0.20 \\
\hline Mallotus philippensis (Lam.) Muell.-Arg. & Euphorbiaceae & 0.20 \\
\hline Oroxylum indicum (L.) Vent. & Bignoniaceae & 0.20 \\
\hline Samanea saman (Jacq.) Merr. & Fabaceae & 0.20 \\
\hline Alstonia macrophylla Wall. ex G Don & Apocynaceae & 0.20 \\
\hline Alstonia scholaris (L.) R Br. & Apocynaceae & 0.20 \\
\hline Calophyllum blancoi Planch. \& Triana & Calophyllaceae & 0.20 \\
\hline Vitex turczaninowii Merr. & Lamiaceae & 0.20 \\
\hline Eucalyptus deglupta Blume & Myrtaceae & 0.20 \\
\hline
\end{tabular}




\begin{tabular}{|l|l|r|}
\hline \multicolumn{1}{|c|}{ Species } & \multicolumn{1}{c|}{ Family } & \multicolumn{1}{c|}{ IV } \\
\hline Terminalia catappa L. & \multicolumn{1}{c|}{ Combretaceae } & 0.20 \\
\hline Leea guineensis G Don & Vitaceae & 0.20 \\
\hline Clausena brevistyla Oliver & Rutaceae & 0.20 \\
\hline Canarium luzonicum (Blume) A Gray & Burseraceae & 0.20 \\
\hline Dracontomelon dao (Blanco) Merr. \& Rolfe & Anacardiaceae & 0.20 \\
\hline Nauclea orientalis (L.) L. & Rubiaceae & 0.20 \\
\hline Cynometra ramiflora L. & Fabaceae & 0.20 \\
\hline Madhuca betis (Blanco) MacBride & Sapotaceae & 0.20 \\
\hline Triplaris cumingiana Fisch. \& Mey. ex CA Mey & Polvgonaceae & 0.20 \\
\hline
\end{tabular}

Endemic Species (see Plate 1 for photos)

The geographical distribution of plant species has been very useful for assessing biodiversity values of regions, countries, and islands (Malabrigo 2013). Species confined to a particular site should be given particular conservation management strategies, as they are more vulnerable to disturbance due to their narrow range. La Mesa Watershed, despite being a reforestation area dominated by plantation species is home to a number Philippine endemics (Table 2). Of the 92 total species recorded, 14 are exclusive to the country for $15.22 \%$ endemism. The recorded endemism is significantly lower compared to the country endemism, reported to be $60 \%$ based on Merrill's Enumeration of Philippine Flowering Plants (1923-1926). This is understandable since the study area is a reforestation site. 
Table 2. List of Philippine Endemics Recorded in the Study Area

\begin{tabular}{|c|c|c|}
\hline Family & Species & Common Name \\
\hline ANACARDIACEAE & Dracontomelon edule (Blanco) Skeels & Lamio \\
\hline \multirow{2}{*}{ BURSERACEAE } & Canarium gracile Engl. & Pagsahingin bulog \\
\hline & Canarium luzonicum (Blume) A Gray & Piling liitan \\
\hline EUPHORBIACEAE & Macaranga bicolor Muell.-Arg. & Hamindang \\
\hline LAMIACEAE & Vitex turczaninowii Merr. & Lingo-lingo \\
\hline \multirow{5}{*}{ MORACEAE } & Artocarpus blancoi (Elmer) Merr. & Antipolo \\
\hline & Artocarpus ovatus Blanco & Anubing \\
\hline & Broussonetia luzonica (Blanco) Bureau var. luzonica & Himbabao \\
\hline & Ficus pseudopalma Blanco & Niog-niogan \\
\hline & Ficus ulmifolia Lam. & Is-is \\
\hline MYRTACEAE & Syzygium calubcob (C Robinson) Merr. & Kalubkob \\
\hline PINACEAE & $\begin{array}{l}\text { Pinus kesiya Royle ex Gordon subsp. insularis (Endl.) } \\
\text { DZ Li }\end{array}$ & Benguet Pine \\
\hline PRIMULACEAE & Ardisia squamulosa $\mathrm{C}$ Presl & Tagpo \\
\hline RHAMNACEAE & Ziziphus talanai (Blanco)Merr. & Balakat \\
\hline
\end{tabular}

Threatened Species (see Plate 2 for photos)

Apart from the endemic species recorded in the area, there are also seven (7) threatened species listed under either the Philippine Red List (Fernando et al. 2008) or the IUCN Red List of Threatened Species (2014.3). Four (4) of which are exclusively found in the country (Table 3). Noteworthy among the list is the critically endangered (CR), superior hardwood species, Narra. It should be noted that Narra could be found in almost every school and eco-parks in the Philippines. However, its population in the wild is extremely threatened. 
Table 3. List of Threatened Species Encountered in La Mesa Watershed

\begin{tabular}{|l|l|l|l|c|}
\hline \multicolumn{1}{|c|}{ Species } & \multicolumn{1}{|c|}{$\begin{array}{c}\text { Common } \\
\text { Name }\end{array}$} & \multicolumn{1}{|c|}{ Family } & IUCN & $\begin{array}{c}\text { Philippine } \\
\text { Red List }\end{array}$ \\
\hline Artocarpus blancoi (Elmer) Merr. & Antipolo & Moraceae & vU & \\
\hline Canarium luzonicum (Blume) A Gray & Piling liitan & Burseraceae & vU & \\
\hline $\begin{array}{l}\text { Dracontomelon dao (Blanco) Merr. } \\
\text { \& Rolfe }\end{array}$ & Dao & Anacardiaceae & & VU \\
\hline $\begin{array}{l}\text { Dracontomelon edule (Blanco) } \\
\text { Skeels }\end{array}$ & Lamio & Anacardiaceae & & VU \\
\hline $\begin{array}{l}\text { Macaranga bicolor Muell.-Arg. } \\
\text { Pterocarpus indicus Willd. forma } \\
\text { indicus }\end{array}$ & Hamindang & Euphorbiaceae & vU & \\
\hline \begin{tabular}{l} 
Vitex parviflora Juss. \\
\hline
\end{tabular} & Marra & Fabaceae & vU & CR \\
\hline
\end{tabular}

\section{CONCLUSIONS}

Results of the study show a rare success story of reforestation efforts in the country. In a short period of 12 years that Bantay Kalikasan took over in the reforestation efforts, La Mesa watershed was re-converted into a young secondary forest that is now homing at least 70 native species. Consequently, the improvement of the vegetation of the watershed, also improves the quality of goods and services it provides. More importantly, the current condition of the watershed is a testimony of success from a public-private partnership endeavor. This should be the best strategy to move forward given the enormous task of protecting and conserving the country's remaining forests with the very limited resources of the government.

\section{LITERATURE CITED}

DellaSala, D.A., A. Martin, R. Spivak, T. Schulke, B. Bird, M. Criley, C. Van Daalen, J. Kreilick, R. Brown, \& G. Aplet

2003 A Citizen's Call for Ecological Forest Restoration: Forest Restoration Principles and Criteria. Ecological Restoration 21(1): 14-23. 
Department of Science and Technology (DOST), Department of Environment and Natural Resources (DENR), Department of Agriculture (DA), and University of the Philippines Los Baños (UPLB)

1999 Guidelines for Watershed Management and Development in the Philippines. Book Series No. 166-1999. 241pp.

Fernando, E.S., L.L. Co, D.A. Lagunzad, W.S. Gruezo, J.F. Barcelona, D.A. Madulid, A. Baja-Lapis, G.I. Texon, A.C. Manila \& P.M. Zamora 2008 Threatened plants of the Philippines: a preliminary assessment. Asia Life Sciences, Supplement 3: 1-52.

Gonenc, I.E., A. Vadineanu, J.P. Wolfin, \& R.C. Russo

2008 Sustainable Use and Development of Watersheds. New York, NY: Springer. 544pp.

IUCN 2014. The IUCN Red List of Threatened Species

2014 http://www.iucnredlist.org>. Downloaded on 17 November 2014.

Malabrigo, P.L.

2013 Vascular flora of the tropical montane forests in BalbalasangBalbalan National Park, Kalinga Province, Northern Luzon, Philippines. Asian Journal of Biodiversity 4 (1): 1-22

Merrill, E.D.

1926 An Enumeration of Philippine Flowering Plants. Vol. I-IV. Bureau of Printing, Manila, Philippines.

Roesch, F.A. Jr.

1993 Adaptive cluster sampling for forest inventories. Forest Science 39(4): 655-669.

Smith, W.B.

2002 Forest inventory and analysis: a national inventory and monitoring program. Environmental Pollution 116: 233-242.

Talvitie, M., Leino, O. \& Holopainen, M.

2006 Inventory of sparse forest populations using adaptive cluster sampling. Silva Fennica 40(1): 101-108. 
Asian Journal of Biodiversity Vol. 6 №. 2

February 2015

Thompson, S.K.

1991 Stratified adaptive cluster sampling. Biometrika 78(2): 389-397.

Tiburan, C.L., Jr., I. Saizen, \& S. Kobayashi.

2012 Spatial Relationship and Ecosystem Management. In N. Uy and R. Shaw. Ecosystem-based Adaptation (pp 197-222). Bingley, UK: Emerald Group Publishing Limited. 


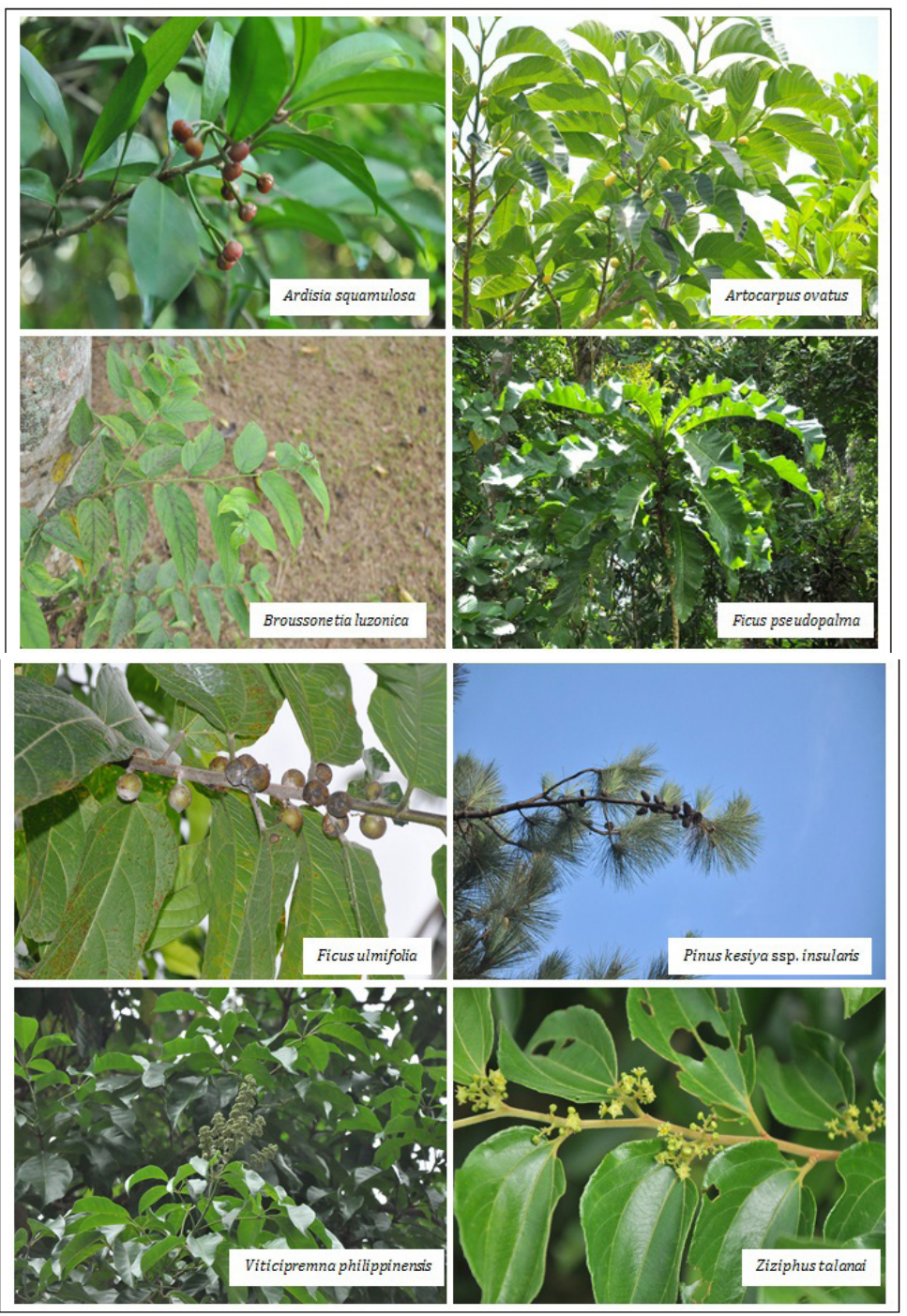

Plate 1. Photos of Endemic Species Present in La Mesa Watershed. 

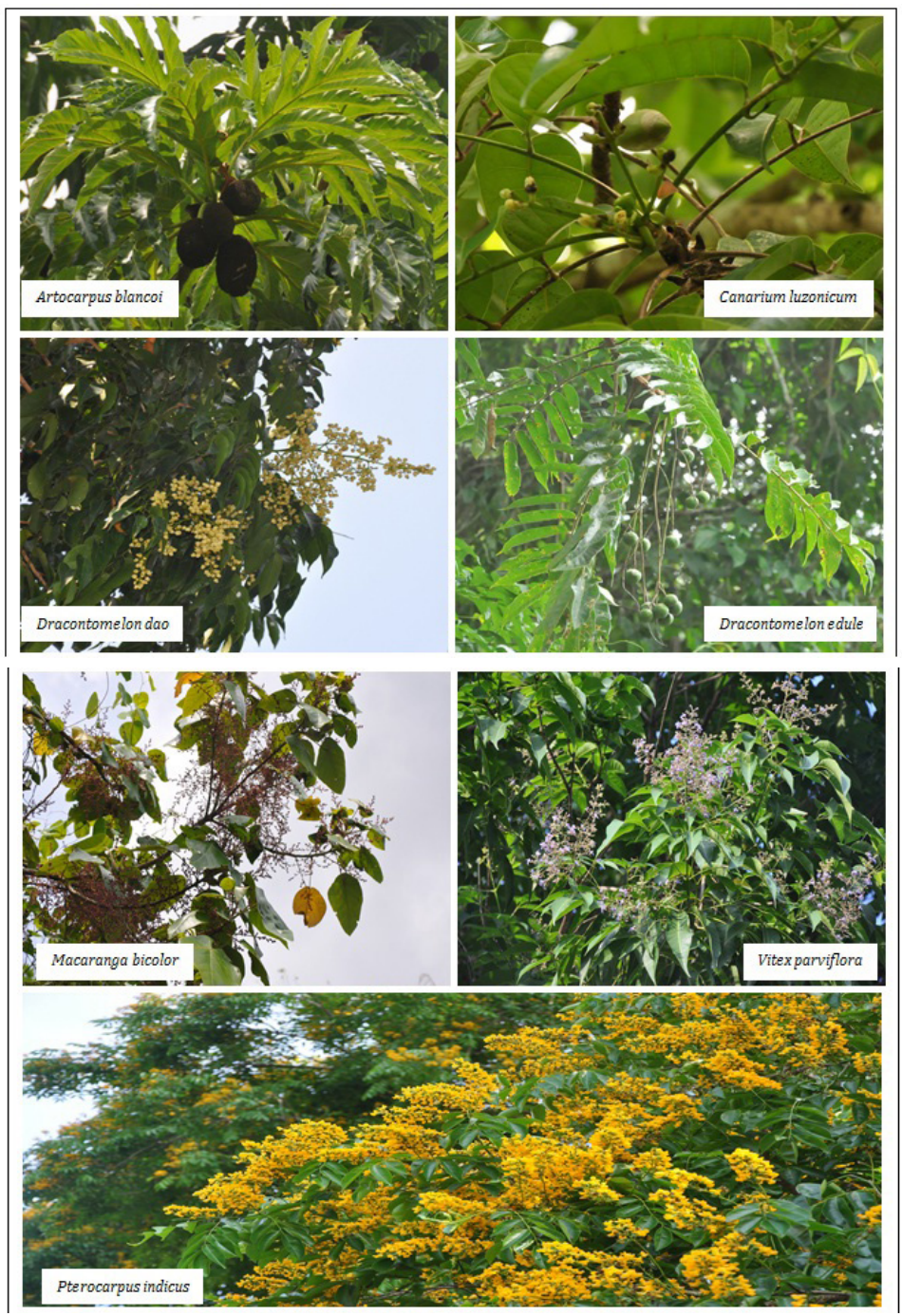

Plate 2. Photos of Threatened Species Present in La Mesa Watershed. 